\title{
Conventions used in this book
}

\section{T R A N S C R I P T I O N}

This book uses the symbols shown in Table 0.1 to transcribe examples and other linguistic data. The table illustrates the pronunciation of the letters of the Arabic alphabet in Modern Standard Arabic.

Table 0.1 Pronounciation of the letters of the Arabic alphabet in Modern Standard Arabic

\begin{tabular}{|c|c|c|c|c|c|c|c|}
\hline 1 & P/ $a / a:$ & $\dot{j}$ & J & ظ & $z$ & ن ن & $m$ \\
\hline ب ب & $b$ & $\jmath$ & $r$ & $\varepsilon$ & $\varsigma$ & 。 & $h$ \\
\hline$ت$ & $t$ & j & $z$ & $\dot{\varepsilon}$ & $\dot{g}$ & 9 & $m / u / u$ : \\
\hline$ث$ & $\theta$ & س س & $s$ & ف & $f$ & ي & $y / i / i$ : \\
\hline ج & $d z / g *$ & ش ش & $\int$ & ق & $q$ & & \\
\hline$\tau$ & $\underline{h}$ & ص & $\underline{s}$ & ك & $k$ & ة. & $-a$ \\
\hline$\dot{\tau}$ & $x$ & ض & $d$ & J & $l$ & 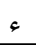 & $?$ \\
\hline د & $d$ & $b$ & $t$ & م & $m$ & & \\
\hline
\end{tabular}

Note: *In Egypt, $g$ is accepted as the MSA pronunciation of the letter $\mathrm{r}$ in addition to ds.

This book uses a broad kind of transcription. However, it should be noted that mainly spoken data is used. Thus there is considerable variation within that data. For instance, the same word could be pronounced by the same speaker first with a long vowel, and then with a short one in the same stretch of discourse. It is important for sociolinguists to capture the performance of speakers rather than the idealised way in which words and phonemes are 'supposed' to be pronounced. Thus, the aim of transcribing the data is not to idealise but to render actual pronunciation.

Within the examples, a forward slash denotes a short pause, while two slashes denote a long pause. 


\section{GL OSSES}

For the benefit of students and researchers who are not necessarily specialised in Arabic, or in all dialects of Arabic, most examples are glossed, except those in which the structure is not highlighted.

In the glosses, whenever verb forms are fully analysed, the gloss follows the translation for verbs in the perfect (which has a suffix conjugation in Arabic) and precedes the translation for verbs in the imperfect (which has a prefix conjugation), while the mood marking of the verb - if present - is glossed in its natural location at the end of the verb unit.

However, the glossing of an example relates to the context of that example and is not always detailed. If the example is intended to demonstrate how individuals switch between two varieties or two languages, and if this demonstration concentrates on specific morpho-syntactic variables (such as demonstratives, negation, tense, aspect, mood marking and case marking) then the glossing is detailed, as in the example below from Chapter 2:

\begin{tabular}{|c|c|c|c|c|}
\hline $\begin{array}{l}\text { ka:na } \\
\text { To be-3msg- } \\
\text { perf } \\
\text { l-ams } \\
\text { det-yesterday }\end{array}$ & $\begin{array}{l}l-g a h d \underline{u} \\
\text { det-effort- } \\
\text { nom }\end{array}$ & $\begin{array}{ll}\text { mustanfaran } & f i \\
\text { exerted-acc } & \text { in }\end{array}$ & $\begin{array}{l}\text { muma:gahati } \\
\text { facing-gen }\end{array}$ & $\begin{array}{l}\text { mufkila:ti } \\
\text { problems- } \\
\text { gen }\end{array}$ \\
\hline
\end{tabular}

If, on the other hand, the example is used to demonstrate an argument which is more related to content, then the glossing is more basic, as in the following example from Chapter 4 :

\section{ya rabb/ daSma min Palb Sumru ma faqad il- Pamal mala il-Pima:n bi:k' Voc God/ prayer from heart never neg lost the hope nor the-faith in-you}

'Oh God. This is a prayer from a heart that never lost hope or belief in you'.

Thus, the glossing is not consistent but changes according to the way the data is analysed. All abbreviations and symbols used are listed above.

Finally, note this last example, from Chapter 4:

لقد دخلت هذه الدار و هي مجرد جدر ان..كانو ال ايو افقون على زو اج أبيكم مني.و كنت (58)

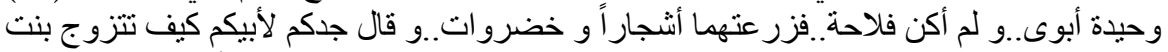

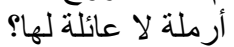

laqad daxaltu ha:ða ad-da:r wa hiya mugarrad gudra:n/ Already enter-1sg-perf this the-house and she only walls 
ka:nu: la: yuma:fiqu:n Sala zama:g Pabi:kum minni:/ be-3mpl- neg 3mpl-agree on marriage father- from-me perf

wa kuntu mahi:dat Pabawayyil

and be-1sg-perf lonely parents-mine

wa lam Pakun falla:ha/ fazaraStuhuma: Pafga:ran wa xudrama:t and neg 1sg-be peasant/ plant-1sg-they trees-acc and vegetables wa qa:la gaddukum li-Pabi:kum/ kayfa

and say-3msg-perf grandfather- to-fatheryour-pl your-pl how

tatazammag bint Parmala la: Sa:Pila laha:/

2msg-marry girl widow neg family to-her

'I had come to your grandfather's house when it was just walls. They did not approve my marriage to your father. I was an only child and I was no peasant then. Since then, I have planted trees and vegetables. Your grandfather then asked your father how he can marry a mere widow with no family.'

This example is in fact, from a novel written in Egypt about Egyptians. I have transcribed it as an Egyptian would read it, with the $g$ rather than the db.

\section{PERSONAL NAMES, TITLES AND TOPONYMS}

This book employs the transliteration scheme of the Library of Congress to transcribe names and titles. This facilitates the search for these materials in Library catalogues, where the same conventions are used (Table 0.2).

Table 0.2 Transliteration scheme of the Library of Congress

\begin{tabular}{|c|c|c|c|c|c|c|c|}
\hline 1 & $\overline{\mathrm{a}}$ & $\dot{~}$ & $\mathrm{dh}$ & ظ & $\mathrm{z}$ & ن ن & $\mathrm{m}$ \\
\hline ب ب & $\mathrm{b}$ & $\jmath$ & $\mathrm{r}$ & $\varepsilon$ & c & . & $\mathrm{h}$ \\
\hline ت & $\mathrm{t}$ & $j$ & $\mathrm{z}$ & $\dot{\varepsilon}$ & gh & 9 & $\mathrm{w} / \overline{\mathrm{u}}$ \\
\hline$ث$ & th & س س & $\mathrm{s}$ & ف & $\mathrm{f}$ & ي & $\mathrm{y} / \overline{1}$ \\
\hline ج & $\mathrm{j}$ & ش ش & $\mathrm{sh}$ & ق & $\mathrm{q}$ & & \\
\hline$\tau$ & $\mathrm{h}$ & ص & $\underline{s}$ & ك5 & $\mathrm{k}$ & 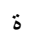 & $-\mathrm{ah}$ \\
\hline$\dot{\tau}$ & kh & ض ض & $\mathrm{d}$ & J & 1 & 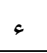 & , \\
\hline د & $\mathrm{d}$ & b & $\mathrm{t}$ & 5 & $\mathrm{m}$ & ى & -á \\
\hline
\end{tabular}

Place-names, or proper names of prominent persons for whom there is a common equivalent in English, are excepted from this rule; hence, I refer to Jamāl 'Abd al-Nāṣir as 'Nasser', and to al-Quds as 'Jerusalem'. Lesser histori- 
cal figures, however, are given in full transliteration, in order to preserve the original form of the name, e.g. Salāmah Mūsá.

\section{CITING AT ONE REMOVE}

I don't give bibliographic details of sources I mention as cited in another work, e.g. for Silverstein (1998) cited in Woolard (2004), I give source details for Woolard but not for Silverstein. 